Volume -X, Issue-01, January-June, 2015

\title{
An Assessment of Entrepreneurial Affinity in Bangladesh: A Comparative Analysis between Small Live Entrepreneurs and Potential Entrepreneurs of University Level Students
}

\author{
SERENA AKTAR ${ }^{*}$
}

\begin{abstract}
:
This is an empirical and quantitative study conducted on small scale live entrepreneurs and potential entrepreneurs of university level students of Bangladesh. The main purpose of this study is to identify and examine the factors influencing decision of becoming an entrepreneur. For fulfilling the study purpose, by using simple random sampling technique a total of 600 questionnaires were administered; 300 were distributed to the students who were interested to become entrepreneurs and 300 questionnaires were also distributed to small scale live entrepreneurs who formed their business during the last two years and more. Data were analyzed according to objectivity. The results indicated that need for achievement is highly influential factor in picking up decision of becoming an entrepreneur of potential entrepreneurs of university level students and family business background is the main influential factor in taking decision of becoming an entrepreneur of the small scale live entrepreneurs. Parallel factors, e.g., locus of control, risk taking propensity and proactive personality also acted as the influential factors of creating entrepreneurial affinity in both of them.
\end{abstract}

Keywords: Entrepreneurs, Entrepreneurial affinity, Locus of control, Need for achievement, Proactive personality, Risk taking propensity, Entrepreneurship education, and Family business background.

\section{INTRODUCTION}

Unemployment is one of the most dangerous problems in all least developed and developing countries. Bangladesh is one of them. Entrepreneurship activity

\footnotetext{
*Assistant Professor of Management, Department of Business Administration, Faculty of Business, Northern University Bangladesh. E-mail:serenanub@gmail.com
} 
is seen as one of the tools to solve unemployment problem. It is defined that entrepreneurship consists of beginning and management of a company (Zeithaml et al, 1987). Entrepreneurship is a highly creative activity encouraged by government policy, social acceptance, creativity and innovation, economic growth, business education, family background and some other psychological factors. Furthermore the family business background shapes the attitudes and willingness of people to start new businesses. It is found that the starting of a new business is a predictor of entrepreneurship activity in all economies (Ayodele, 2013). Family business background provides people a comparative advantage in starting a new venture (Chang et al., 2009). Individuals' attitudes are determined with preceding experience (Krueger 1993). Additionally education is affecting attitudes, norms, perceptions and behavior which may be responsible factors in picking up the decision of becoming entrepreneurs. Previous researchers indicated that entrepreneurship education could improve an individual's selfefficacy (Wilson et al 2007).

The paper begins with a review of factors which are supposed to affect entrepreneurial development. Then, it will describe study methodology. The paper will then present empirical results and the analysis based on the results. The paper will conclude with major findings and a number of recommendations.

\section{LITERATURE REVIEW}

Entrepreneurship is supposed to be a function of various factors: government support, economical condition, social acceptance, family background, education, psychological factors e.g. locus of control, desire for independence, risk taking propensity, proactive personality. A variety of studies have been brought forth findings about the aforementioned factors separately. As this paper is concerned with locus of control, need for achievement, risk taking propensity, proactive personality and business education, the discussion made below belongs to these factors only.

Locus of control is one of the most studied psychological traits in entrepreneurship researches. An individual having internal locus of control get influenced in becoming an entrepreneur. Rotter (1966) defined that "locus of control refers to a generalized belief that a person can or cannot control his or her own destiny". An individual having external locus of control believes that his/her behaviors are under influence of outside forces (Rotter 1990). There is a positive relationship between internal locus of control and entrepreneurship intention (Perry 1990). Brockhaus and Horowitz (1986) found that entrepreneurs have an internal locus of control orientation more than externals. It is also supported that an internal locus of control has been one of the psychological characteristics to the development of entrepreneurship (Kaufmann and Walsh 1995). 
According to Robbins (2003), moderate risk taking propensity has a positive influence on becoming entrepreneurs. Brockhaus (1980) identified that risk taking propensity affects on becoming entrepreneurs.

Robbins (2003) defined that need for achievement is a drive to achieve in relation to a set of standards and to strive to succeed. It is revealed that need for achievement is strongly influenced by the entrepreneurship intention (Duygulu, 2008). Littunen (2000) suggested that individuals who have need for achievement demonstrate a high performance in challenging tasks and there is a possibility to become an entrepreneur. Bateman and Grant (1993) revealed that proactive personality is measured as a personal character on the way to behave and take action to influence a situation. They also concluded that proactive personality helps an individual to find out opportunities which is helpful to become an entrepreneur. Brief and Aldag (1981) found that proactive personality plays an influencing role in starting a business. Zeithaml and Zeithaml (1984) also revealed that proactive personality is a strategy of managing new venture.

N. Krueger (1993) suggested that family business background is an important factor in a start-up to entrepreneurship. There is a significant relationship between family business background and entrepreneurial intention in university level students (M. Z. Zahariah et al, 2010). Carr and Sequeira (2007) found that family business background has influence on intentions to become entrepreneur. Entrepreneurial education is that entrepreneurship characteristics, attitudes and skills can be developed. Business education is helping to create a new product or service of existing business or to start a new business (Hanesmark, 1998).

\section{OBJECTIVES OF THE STUDY}

From the review of literature on entrepreneurial development, identifying gaps in the existing knowledge, the study formulates the study-objectives.

a) Identification of the most responsible factors of influence on picking up entrepreneurship decision by entrepreneurial affinity among small scale live (already active) entrepreneurs and potential entrepreneurs of university level students.

b) Building a model to explore as to how the responsible factors of influence on picking up entrepreneurship decision by entrepreneurial affinity among small scale live entrepreneurs and potential entrepreneurs of university level students.

c) The final objective of the study is to analyze the responsible factors of influence on picking up entrepreneurship decision by entrepreneurial affinity among small scale live entrepreneurs and potential entrepreneurs of university level students. 
THEORETICAL FRAMEWORK OF THE STUDY

Figure 1: Factors of influencing entrepreneurial

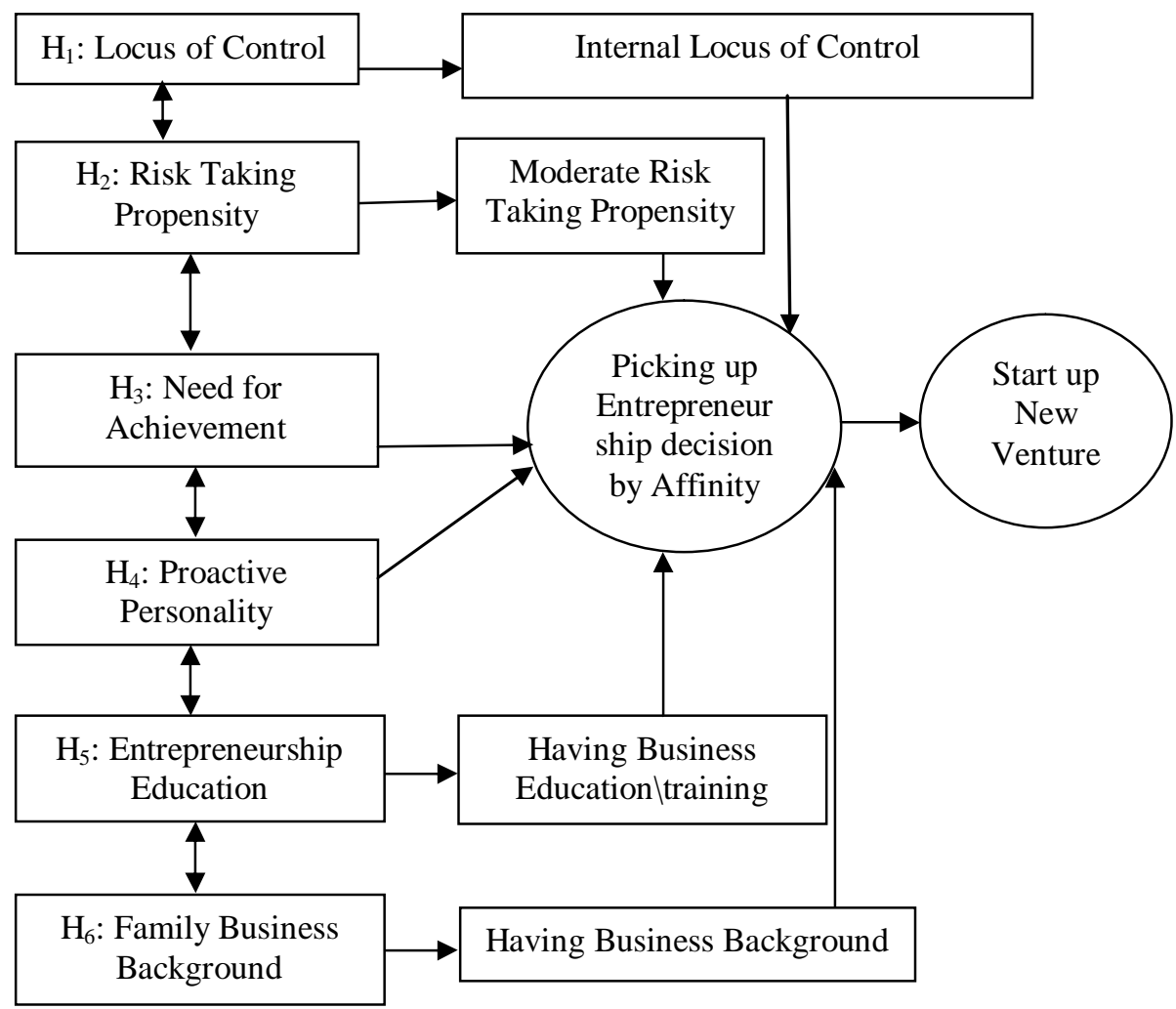

Source: Compiled by author

\section{METHODOLOGY}

This study was carried out through a survey method; Questionnaire as the main instrument which was designed on the basis of objectives and hypotheses. The questionnaire consisted of two parts. Part I consisted of the demographic information and Part II consisted of the responsible factors of influence on picking up entrepreneurship decision by entrepreneurial affinity among small scale live entrepreneurs and potential entrepreneurs of the university level students. A five point scale from strongly disagree (1) to strongly agree (5) was adopted to identify the influential factors of picking up entrepreneurship decision. 


\section{STATEMENT OF THE HYPOTHESES}

$\mathbf{H}_{1 \mathbf{a}}$ : Locus of control has a positive influence on picking up entrepreneurship decision by entrepreneurial affinity of small scale live entrepreneurs.

$\mathbf{H}_{1 \mathbf{b}}$ : Locus of control has a positive influence on picking up entrepreneurship decision by entrepreneurial affinity of potential entrepreneurs of university level students.

$\mathbf{H}_{2 \mathbf{a}}$ : Risk taking propensity has a positive influence on picking up entrepreneurship decision by entrepreneurial affinity of small scale live entrepreneurs.

$\mathbf{H}_{2 \mathbf{b}}$ : Risk taking propensity has a positive influence on picking up entrepreneurship decision by entrepreneurial affinity of potential entrepreneurs of university level students.

$\mathbf{H}_{3 \mathbf{a}}$ : Need for achievement has a positive influence on picking up entrepreneurship decision by entrepreneurial affinity of small scale live entrepreneurs.

$\mathbf{H}_{3 \mathbf{b}}$ : Need for achievement has a positive influence on picking up entrepreneurship decision by entrepreneurial affinity of potential entrepreneurs of university level students.

$\mathbf{H}_{4 \mathbf{a}}$ : Proactive personality has a positive influence on picking up entrepreneurship decision by entrepreneurial affinity of small scale live entrepreneurs.

$\mathbf{H}_{\mathbf{4 b}}$ : Proactive personality has a positive influence on picking up entrepreneurship decision by entrepreneurial affinity of potential entrepreneurs of university level students.

$\mathbf{H}_{5 \mathbf{a}}$ : Entrepreneurship educationltraining has a positive influence on picking up entrepreneurship decision by entrepreneurial affinity of small scale live entrepreneurs.

$\mathbf{H}_{5 \mathbf{5}}$ : Entrepreneurship education $\backslash$ training has a positive influence on picking up entrepreneurship decision by entrepreneurial affinity of potential entrepreneurs of university level students.

$\mathbf{H}_{\mathbf{6} \mathbf{a}}$ : Family business background has a positive influence on picking up entrepreneurship decision by entrepreneurial affinity of small scale live entrepreneurs.

$\mathbf{H}_{6 \mathbf{b}}$ : Family business background has a positive influence on picking up entrepreneurship decision by entrepreneurial affinity of potential entrepreneurs of university level students. 
Sampling Technique: Due to the scarcity of time at the disposal of the researcher, this study was confined to 300 samples of small-scale live entrepreneurs of Bangladesh. The survey conducted from June to October, 2014. Different types of enterprises, which were formed during 2(two) years and more, were included in this study. Types of businesses were food stored, clothing stores, book stores, drugstores, hotels, beauty shops, electronics and hardware etc.

Random sampling method was also used to select the potential entrepreneur of university level students. A total 300 questionnaires were distributed to students (potential entrepreneurs) of 15 major universities of Bangladesh i.e. World University Bangladesh, University of Liberal Arts of Bangladesh, Stamford University Bangladesh, BRAC University, ASA University Bangladesh, East West University, Dhaka University; Institute of Business Administration(IBA), Daffodil International University, International Islamic University of Chittagong, North South University, Northern University Bangladesh, South East University, State University of Bangladesh, United International University, University of Dhaka. Among 300;280 copies of questionnaire were received back, 19 were incomplete and 20 were not received.

\section{Data analysis:}

In order to fulfill the objectives of this study the data have been analyzed by using the statistical package SPSS version -20(IBM) as well as the following statistical tools has been applied to analyze the data:

1. Reliability analysis

2. Descriptive statistics (Frequency Distribution)

3. Correlation analysis

4. Hypothesis Testing

VI. RESULTS AND DISCUSSION

\subsection{Reliability Analysis:}

TABLE-I

RELIABILITY RESULTS

\begin{tabular}{lcc}
\hline Variables & Cronbach's Alpha & N of Items \\
\hline $\begin{array}{l}\text { Small scale live entrepreneurs } \\
\begin{array}{l}\text { Potential entrepreneurs of university } \\
\text { level students }\end{array}\end{array}$ & 0.777 & 6 \\
\hline
\end{tabular}


Table-I shows the internal reliability, internal reliability of the instrument was checked by using Cronbach's alpha. The results of Cronbach alpha were 0.777 (small scale live entrepreneurs) and 0.714 (potential entrepreneurs of university level students) which were above the standard presented by (Nunnally, 1978) that was 0.70. Therefore, this is proved that the instrument used in this study had strong internal reliability and it could be used with confidence for the application for further statistical analysis and interpretation.

\subsection{Descriptive statistics (Mean and Standard deviation):}

TABLE-II (A)

DEMOGRAPHIC PROFILE OF THE SMALL SCALE LIVE ENTREPRENEURS

\begin{tabular}{l|c|c|c|c}
\hline Variables & Frequency & Percent & Mean & $\begin{array}{c}\text { Standard } \\
\text { Deviation }\end{array}$ \\
\hline Gender & & & $\mathbf{1 . 1 4}$ & $\mathbf{0 . 3 4 4}$ \\
Male & 259 & 86.3 & & \\
Female & 41 & 13.7 & & \\
Total & 300 & 100.0 & $\mathbf{1 . 6 1}$ & $\mathbf{0 . 5 8 7}$ \\
Age & & & & \\
18-24 & 132 & 44.0 & & \\
25-35 & 152 & 50.7 & & \\
36-45 & 16 & 5.3 & & \\
Total & 300 & 100.0 & & \\
Educational ability & & & $\mathbf{1 . 5 8}$ & \\
S.S.C & 204 & 68.0 & & \\
H.S.C & 22 & 7.3 & & \\
Graduate & 69 & 23.0 & & \\
Post graduate & 5 & 1.7 & & \\
Total & 300 & 100.0 & & \\
Marital Status & & & $\mathbf{1 . 6 4}$ & \\
Single & 107 & 35.7 & & $\mathbf{1 . 3 5 5}$ \\
Married & 193 & 64.3 & & \\
Total & 300 & 100.0 & & \\
Experience & & & & \\
2-4 & 126 & 42.0 & & \\
5-6 & 88 & 29.3 & & \\
7-8 & 29 & 9.7 & & \\
9-10 & 22 & 7.3 & & \\
10 and above & 35 & 11.7 & & \\
Total & 300 & 100.0 & & \\
\hline Sorre: Feld & & & \\
\hline
\end{tabular}

Source: Field survey June-October, 2014 
Table-II (A) shows that, out of 300 respondents; most of them (259) were male and rest 41 were female. The mean score of the respondents' gender is 1.14 and standard deviation is 0.344 . Table presents the age distribution of the respondents. Among 300 respondents; 152 respondents' age range were 2535years, next highest 132 respondents were in the range of age 18-14 years and age range from 36 years to 45 years, number of respondents is 16 . So majority of the respondents belonged to young age group. The mean score of the respondents' age is 1.61 and standard deviation is 0.587 . Table visibly presents the educational ability of the respondents which implies among 300 respondents; 204 respondents completed only SSC, 69 respondents were Graduate, 22 completed HSC and only 5 were post graduate degree holder. The mean score of the respondents' educational qualification is 1.58 and standard deviation is 0.898. Table shows the marital status of the respondents. Among all of the respondents; most of the respondents (193) of this study were married and rests 107 were unmarried respondents. The mean score of the respondents' marital status is 1.64 and standard deviation is 0.480 . A total number of 126 respondents having 2 to 4 years experiences, 88 respondents having 5-6 years experiencce,7-8 years experience having by 29 respondents, 22 respondents having 9 years to 10 years experience and 35 respondents having above 10 years business experience. The mean score of the respondents' business experience is 2.17 and standard deviation is 1.355 .

TABLE-II (B)

DEMOGRAPHIC PROFILE OF THE POTENTIAL ENTREPRENEURS OF UNIVERSITY LEVEL STUDENTS

\begin{tabular}{l|c|c|c|c}
\hline Variables & Frequency & Percent & Mean & $\begin{array}{l}\text { Standard } \\
\text { Deviation }\end{array}$ \\
\hline \multicolumn{1}{c}{ Gender } & & & $\mathbf{1 . 1 6}$ & $\mathbf{0 . 3 6 5}$ \\
Male & 220 & 84.3 & & \\
Female & 41 & 15.7 & & \\
Total & 261 & 100.0 & & $\mathbf{0 . 4 8 3}$ \\
Age & & & $\mathbf{1 . 3 4}$ & \\
$18-24$ & 174 & 66.7 & & \\
$25-35$ & 87 & 33.3 & & $\mathbf{0 . 8 2 3}$ \\
Total & 261 & 100.0 & & \\
Educational ability & & & $\mathbf{1 . 4 3}$ & \\
Graduate & 205 & 78.5 & & \\
Post graduate & 56 & 21.5 & & \\
\hline
\end{tabular}




\begin{tabular}{l|c|c|c|c}
\hline Variables & Frequency & Percent & Mean & $\begin{array}{l}\text { Standard } \\
\text { Deviation }\end{array}$ \\
\hline Total & 261 & 100.0 & & \\
Marital Status & & & $\mathbf{1 . 1 3}$ & $\mathbf{0 . 3 3 3}$ \\
Single & 228 & 87.4 & & \\
Married & 33 & 12.6 & & \\
Total & 261 & 100.0 & & $\mathbf{0 . 6 9 4}$ \\
Experience & & & $\mathbf{1 . 5 2}$ & \\
0 & 149 & 57.1 & & \\
$1-3$ & 89 & 34.1 & & \\
$4-5$ & 20 & 7.7 & & \\
$5-6$ & 3 & 1.1 & & \\
Total & 261 & 100.0 & & \\
\hline
\end{tabular}

Source: Field survey June-October, 2014

Table-II (B) shows that, out of 261 respondents, most of them (220) were male and rest 41 were female. The mean score of the respondents' gender is 1.16(standard deviation is 0.365). Table also presents the age distribution of the respondents. Among 261 respondents 174 respondents' age range were 18-24 years, and 87 respondents were in the range of age 25-35. The mean score of the respondents' age is 1.34 (standard deviation is 0.483 ). The above table shows the educational ability of the respondents. Among 261 respondents, 205 respondents were in graduate level and 56 respondents were post graduate level. The mean score of the respondents' educational qualification is 1.43 (standard deviation is 0.823). Table shows marital status of the respondents. Among all of the respondents, most of the respondents (228) of this study were married and rests 33 respondents were unmarried. The mean score of the respondents' marital status is 1.13 (standard deviation is 0.333 ). A total number of 149 respondents having no experiences, 89 respondents having 1-3 years experiencce, 4-5 years experience having by 20 respondents and only 3 respondents having 5 years to 6 years experience. The mean score of the respondents' business experience is 1.52 (standard deviation is 0.694). 


\subsection{Hypothesis Testing:}

TABLE III-(A)

ONE -WAY - ANOVA (SMALL SCALE LIVE ENTREPRENEURS)

\begin{tabular}{|c|c|c|c|c|c|c|}
\hline & & $\begin{array}{l}\text { Sum of } \\
\text { Squares }\end{array}$ & $\mathrm{df}$ & $\begin{array}{c}\text { Mean } \\
\text { Square }\end{array}$ & $F$ & $\mathrm{Sig}$ \\
\hline \multirow{3}{*}{$\begin{array}{l}\text { Locus of } \\
\text { Control }\end{array}$} & Between Groups & 1410.241 & 26 & 54.240 & 3.046 & .000 \\
\hline & Within Groups & 4861.289 & 273 & 17.807 & & \\
\hline & Total & 6271.530 & 299 & & & \\
\hline \multirow{3}{*}{$\begin{array}{l}\text { Risk Taking } \\
\text { Propensity }\end{array}$} & Between Groups & 1042.243 & 26 & 40.086 & 1.978 & .004 \\
\hline & Within Groups & 5531.394 & 273 & 20.262 & & \\
\hline & Total & 6573.637 & 299 & & & \\
\hline \multirow{3}{*}{$\begin{array}{l}\text { Need for } \\
\text { achievement }\end{array}$} & Between Groups & 1769.269 & 26 & 68.049 & 3.460 & .000 \\
\hline & Within Groups & 5369.568 & 273 & 19.669 & & \\
\hline & Total & 7138.837 & 299 & & & \\
\hline \multirow{3}{*}{$\begin{array}{l}\text { Proactive } \\
\text { Personality }\end{array}$} & Between Groups & 1640.822 & 26 & 63.109 & 2.728 & .000 \\
\hline & Within Groups & 6316.574 & 273 & 23.138 & & \\
\hline & Total & 7957.397 & 299 & & & \\
\hline \multirow{3}{*}{$\begin{array}{l}\text { Entrepreneurs } \\
\text { hip education } \\
\text { program }\end{array}$} & Between Groups & 1543.405 & 26 & 59.362 & 4.833 & .000 \\
\hline & Within Groups & 3353.165 & 273 & 12.283 & & \\
\hline & Total & 4896.570 & 299 & & & \\
\hline \multirow{3}{*}{$\begin{array}{l}\text { Family } \\
\text { Business } \\
\text { Background }\end{array}$} & Between Groups & 171.043 & 26 & 6.579 & 4.752 & .000 \\
\hline & Within Groups & 377.943 & 273 & 1.384 & & \\
\hline & Total & 548.987 & 299 & & & \\
\hline
\end{tabular}

ANOVA (small scale live entrepreneurs and potential entrepreneurs of university level students) splits the total variance into explained variance (between groups) and unexplained variance (within groups), the variance is defined as $\operatorname{Var}(\mathrm{x})=$ sum of squares(x) / degrees of freedom(x). The F- value, which is the critical test value that is needed for the ANOVA is defined as $\mathrm{F}=$ Varb / Varw .

The above table III (A) shows that in the case of locus of control, the value of between groups is 1410.241 , the value of within groups is 4861.289 and value of $\mathrm{F}$ - test is 3.046. The $\mathrm{P}$ value of locus of control is $0.000(\mathrm{p}<0.001)$ which implies that the null hypothesis is rejected and alternative hypothesis is accepted; In the case of risk taking propensity, the value of between groups is 1042.243, the value of within groups is 5531.394 and value of $\mathrm{F}$ - test is 1.978 . The $\mathrm{P}$ value 
of risk taking propensity is $0.000(\mathrm{P}<0.01)$ which implies that the null hypothesis is rejected and alternative hypothesis is accepted; In the case of risk taking propensity, the value of between groups is 1042.243 , the value of within groups is 5531.394 and value of $\mathrm{F}$ - test is 1.978 . The $\mathrm{P}$ value of risk taking propensity is $0.004(\mathrm{P}<0.01)$ which implies that the null hypothesis is rejected and alternative hypothesis is accepted; In the case of need for achievement, the value of between groups is 1769.269 , the value of within groups is 5369.568 and value of $\mathrm{F}$ - test is 3.460. The $\mathrm{P}$ value of need for achievement is $0.000(\mathrm{P}<0.01)$ which implies that the null hypothesis is rejected and alternative hypothesis is accepted; In the case of need for achievement, the value of between groups is 1769.269, the value of within groups is 5369.568 and value of $\mathrm{F}$ - test is 3.460 . The $\mathrm{P}$ value of need for achievement is $0.000(\mathrm{P}<0.01)$ which implies that the null hypothesis is rejected and alternative hypothesis is accepted; In the case of proactive personality, the value of between groups is 1640.822 , the value of within groups is 6316.574 and value of $\mathrm{F}$ - test is 2.728 . The $\mathrm{P}$ value of proactive personality is $0.000(\mathrm{P}<0.01)$ which implies that the null hypothesis is rejected and alternative hypothesis is accepted; In the case of entrepreneurship education program, the value of between groups is 1543.405 , the value of within groups is 3353.165 and value of $F$ - test is 4.833. The $P$ value of entrepreneurship education program is $0.000(\mathrm{P}<0.01)$ which implies that the null hypothesis is rejected and alternative hypothesis is accepted; In the case of family business background, the value of between groups is 171.043 , the value of within groups is 377.943 and value of $\mathrm{F}$ - test is 4.752 . The $\mathrm{P}$ value of family business background is $0.000(\mathrm{P}<$ 0.01) which implies that the null hypothesis is rejected and alternative hypothesis is accepted; So, all the null hypotheses are rejected which implies the independent variable has positive influence on the dependent variable.

TABLE-III (B)

\section{ONE -WAY ANOVA (POTENTIAL ENTREPRENEURS OF UNIVERSITY LEVEL STUDENTS)}

\begin{tabular}{ll|c|c|c|c|c}
\hline & & $\begin{array}{c}\text { Sum of } \\
\text { Squares }\end{array}$ & df & $\begin{array}{c}\text { Mean } \\
\text { Square }\end{array}$ & F & Sig. \\
\hline \multirow{2}{*}{$\begin{array}{l}\text { Locus of } \\
\text { Control }\end{array}$} & Between Groups & 1169.698 & 15 & 77.980 & 4.753 & .000 \\
& Within Groups & 4019.267 & 245 & 16.405 & & \\
& Total & 5188.966 & 260 & & & \\
Risk Taking & Between Groups & 735.987 & 15 & 49.066 & 2.493 & .002 \\
Propensity & Within Groups & 4822.771 & 245 & 19.685 & & \\
\multirow{2}{*}{ Need for } & Total & 5558.759 & 260 & & & \\
\hline
\end{tabular}




\begin{tabular}{|c|c|c|c|c|c|c|}
\hline \multirow{3}{*}{ achievement } & & $\begin{array}{l}\text { Sum of } \\
\text { Squares }\end{array}$ & $\mathrm{df}$ & $\begin{array}{c}\text { Mean } \\
\text { Square }\end{array}$ & $F$ & Sig. \\
\hline & Within Groups & 4836.431 & 245 & 19.741 & & \\
\hline & Total & 6287.893 & 260 & & & \\
\hline \multirow{3}{*}{$\begin{array}{l}\text { Proactive } \\
\text { Personality }\end{array}$} & Between Groups & 1472.204 & 15 & 98.147 & 4.437 & .000 \\
\hline & Within Groups & 5418.884 & 245 & 22.118 & & \\
\hline & Total & 6891.088 & 260 & & & \\
\hline \multirow{3}{*}{$\begin{array}{l}\text { Entrepreneur } \\
\text { ship } \\
\text { education } \\
\text { program }\end{array}$} & Between Groups & 512.499 & 15 & 34.167 & 3.797 & .000 \\
\hline & Within Groups & 2204.520 & 245 & 8.998 & & \\
\hline & Total & 2717.019 & 260 & & & \\
\hline \multirow{3}{*}{$\begin{array}{l}\text { Family } \\
\text { Business } \\
\text { Background }\end{array}$} & Between Groups & 8.619 & 15 & .575 & 1.209 & .265 \\
\hline & Within Groups & 116.469 & 245 & .475 & & \\
\hline & Total & 125.088 & 260 & & & \\
\hline
\end{tabular}

The above table III (B) shows that in the case of locus of control, the value of between groups is 1169.698 , the value of within groups is 4019.267 and value of $\mathrm{F}$ - test is 4.753. The $\mathrm{P}$ value of locus of control is $0.000(\mathrm{p}<0.001)$ which implies that the null hypothesis is rejected and alternative hypothesis is accepted; In the case of risk taking propensity, the value of between groups is 735.987 , the value of within groups is 4822.771 and value of $F$ - test is 2.493 . The $\mathrm{P}$ value of risk taking propensity is $0.002(\mathrm{P}<0.01)$ which implies that the null hypothesis is rejected and alternative hypothesis is accepted; In the case of need for achievement, the value of between groups is 1451.462 , the value of within groups is 4836.431and value of F- test is 4.902. The $\mathrm{P}$ value of need for achievement is $0.000(\mathrm{P}<0.01)$ which implies that the null hypothesis is rejected and alternative hypothesis is accepted; In the case of need for achievement, the value of between groups is 1769.269 , the value of within groups is 5369.568 and value of $\mathrm{F}$ - test is 3.460. The $\mathrm{P}$ value of need for achievement is $0.000(\mathrm{P}<0.01)$ which implies that the null hypothesis is rejected and alternative hypothesis is accepted; In the case of proactive personality, the value of between groups is 1472.204, the value of within groups is 5418.884 and value of F- test is 4.437. The $\mathrm{P}$ value of proactive personality is $0.000(\mathrm{P}<0.01)$ which implies that the null hypothesis is rejected and alternative hypothesis is accepted; In the case of entrepreneurship education program, the value of between groups is 512.499 , the value of within groups is 2204.520 and value of $F$ - test is 3.797 . The $P$ value of entrepreneurship education program is $0.000(\mathrm{P}<0.01)$ which implies that the null hypothesis is rejected and alternative hypothesis is accepted. So, all the null hypotheses are rejected which implies the independent variable has positive influence on the dependent variable. 
In the case of family business background, the value of between groups is 8.619 , the value of within groups is 116.469 and value of $\mathrm{F}$ - test is 1.209 . The $\mathrm{P}$ value of family business background is $0.265(\mathrm{P}>0.01$ and 0.05$)$ which implies that the alternative hypothesis is rejected and null hypothesis is accepted. So, the null hypothesis are accepted which implies the independent variable has no positive influence on the dependent variable.

TABLE-IV

\section{RESULTS OF SUMMARY OF HYPOTHESES}

\begin{tabular}{|c|c|c|}
\hline \multicolumn{2}{|c|}{ Hypotheses } & \multirow{2}{*}{$\begin{array}{l}\text { Result } \\
\text { Strongly } \\
\text { Supported }\end{array}$} \\
\hline $\mathrm{H}_{1 \mathrm{a}}$ & $\begin{array}{l}\text { Locus of control has a positive influence on picking up entrepreneurship } \\
\text { decision by entrepreneurial affinity of small scale live entrepreneurs. }\end{array}$ & \\
\hline $\mathbf{H}_{1 \mathrm{~b}:}$ & $\begin{array}{l}\text { Locus of control has a positive influence on picking up entrepreneurship } \\
\text { decision by entrepreneurial affinity of potential entrepreneurs of university } \\
\text { level students. }\end{array}$ & $\begin{array}{l}\text { Strongly } \\
\text { Supported }\end{array}$ \\
\hline $\mathbf{H}_{2 \mathrm{a}}$ : & $\begin{array}{l}\text { Risk taking propensity has a positive influence on picking up } \\
\text { entrepreneurship decision by entrepreneurial affinity of small scale live } \\
\text { entrepreneurs. }\end{array}$ & $\begin{array}{l}\text { Strongly } \\
\text { Supported }\end{array}$ \\
\hline $\mathbf{H}_{2 b}$ : & $\begin{array}{l}\text { Risk taking propensity has a positive influence on picking up } \\
\text { entrepreneurship decision by entrepreneurial affinity of potential } \\
\text { entrepreneurs of university level students. }\end{array}$ & $\begin{array}{l}\text { Strongly } \\
\text { Supported }\end{array}$ \\
\hline $\mathbf{H}_{3 \mathrm{a}}$ : & $\begin{array}{l}\text { Need for achievement has a positive influence on picking up } \\
\text { entrepreneurship decision by entrepreneurial affinity of small scale live } \\
\text { entrepreneurs. }\end{array}$ & $\begin{array}{l}\text { Strongly } \\
\text { Supported }\end{array}$ \\
\hline $\mathbf{H}_{3 b}$ : & $\begin{array}{l}\text { Need for achievement has a positive influence on picking up } \\
\text { entrepreneurship decision by entrepreneurial affinity of potential } \\
\text { entrepreneurs of university level students. }\end{array}$ & $\begin{array}{l}\text { Strongly } \\
\text { Supported }\end{array}$ \\
\hline $\mathbf{H}_{4 a}$ : & $\begin{array}{l}\text { Proactive personality has a positive influence on picking up } \\
\text { entrepreneurship decision by entrepreneurial affinity of small scale live } \\
\text { entrepreneurs. }\end{array}$ & $\begin{array}{l}\text { Strongly } \\
\text { Supported }\end{array}$ \\
\hline $\mathbf{H}_{4 b}$ : & $\begin{array}{l}\text { Proactive personality has a positive influence on picking up } \\
\text { entrepreneurship decision by entrepreneurial affinity of potential } \\
\text { entrepreneurs of university level students. }\end{array}$ & $\begin{array}{l}\text { Strongly } \\
\text { Supported }\end{array}$ \\
\hline $\mathbf{H}_{5 \mathrm{a}}$ : & $\begin{array}{l}\text { Entrepreneurship education training has a positive influence on picking up } \\
\text { entrepreneurship decision by entrepreneurial affinity of small scale live } \\
\text { entrepreneurs. }\end{array}$ & $\begin{array}{l}\text { Strongly } \\
\text { Supported }\end{array}$ \\
\hline $\mathbf{H}_{5 \mathrm{~b}}$ : & $\begin{array}{l}\text { Entrepreneurship education training has a positive influence on picking up } \\
\text { entrepreneurship decision by entrepreneurial affinity of potential } \\
\text { entrepreneurs of university level students. }\end{array}$ & $\begin{array}{l}\text { Strongly } \\
\text { Supported }\end{array}$ \\
\hline $\mathbf{H}_{6 \mathrm{a}}$ : & $\begin{array}{l}\text { Family business background has a positive influence on picking up } \\
\text { entrepreneurship decision by entrepreneurial affinity of small scale live } \\
\text { entrepreneurs. }\end{array}$ & $\begin{array}{l}\text { Strongly } \\
\text { Supported }\end{array}$ \\
\hline $\mathbf{H}_{6 \mathrm{~b}}$ : & $\begin{array}{l}\text { Family business background has a positive influence on picking up } \\
\text { entrepreneurship decision by entrepreneurial affinity of potential } \\
\text { entrepreneurs of university level students. }\end{array}$ & Rejected \\
\hline
\end{tabular}




\subsection{Correlation}

TABLE-V

CORRELATION OF SMALL SCALE LIVE ENTREPRENEURS \& POTENTIAL ENTREPRENEURS OF UNIVERSITY LEVEL STUDENTS

\begin{tabular}{l|c|c|c|c}
\hline \multirow{2}{*}{ Variables } & \multicolumn{2}{c|}{$\begin{array}{c}\text { Small scale live } \\
\text { entrepreneurs }\end{array}$} & \multicolumn{2}{c}{$\begin{array}{c}\text { Potential entrepreneurs of } \\
\text { university level students }\end{array}$} \\
\cline { 2 - 5 } & $\begin{array}{c}\text { Correlation } \\
(\mathrm{r})\end{array}$ & P-value & $\begin{array}{c}\text { Correlation ( } \\
\mathrm{r})\end{array}$ & P-value \\
\hline Locus of Control & $.225^{* *}$ & .000 & $.390^{* *}$ & .000 \\
Risk Taking Propensity & $.274^{* *}$ & .000 & $.272^{* *}$ & .000 \\
Need for achievement & $.236^{* *}$ & .000 & $.400^{* *}$ & .000 \\
Proactive propensity & $.279^{* *}$ & .000 & $.368^{* *}$ & .000 \\
Entrepreneurship education & $.205^{* *}$ & .000 & $.357^{* *}$ & .000 \\
Family business background & $.410^{* *}$ & .000 & -.106 & .089 \\
\hline
\end{tabular}

**. Correlation is significant at the 0.01 level (2-tailed).

*. Correlation is significant at the 0.05 level (2-tailed).

The analysis of the results indicate that there is a significant positive correlation between entrepreneurial affinity and locus of control $\left(\mathrm{r}=0.225^{* *}\right.$, $\mathrm{p}<0.01)$; entrepreneurial affinity and risk taking propensity $\left(\mathrm{r}=0.274^{* *}, \mathrm{p}<0.01\right)$; entrepreneurial affinity and need for achievement $\left(\mathrm{r}=0.236^{* *}, \mathrm{p}<0.01\right)$; entrepreneurial affinity and proactive propensity $\left(\mathrm{r}=0.279^{* *}, \quad \mathrm{p}<0.01\right)$; entrepreneurial affinity and entrepreneurship education $\left(\mathrm{r}=0.205^{* *}, \mathrm{p}<0.01\right)$; entrepreneurial affinity and family business background $\left(r=0.410^{* *}, p<0.01\right)$ of small scale live entrepreneurs.

The analysis of the results indicate that there is a significant positive correlation between entrepreneurial affinity and locus of control $\left(r=0.390^{* *}\right.$, $\mathrm{p}<0.01)$; entrepreneurial affinity and risk taking propensity $\left(\mathrm{r}=0.272^{* *}, \mathrm{p}<0.01\right)$; entrepreneurial affinity and need for achievement $\left(\mathrm{r}=0.400^{* *}, \mathrm{p}<0.01\right)$; entrepreneurial affinity and proactive propensity $\left(\mathrm{r}=0.368^{* *}, \mathrm{p}<0.01\right)$; entrepreneurial affinity and entrepreneurship education $\left(r=0.357^{* *}, p<0.01\right)$ of potential entrepreneurs of university level students. There is a negative correlation between entrepreneurial affinity and family business background ( $\mathrm{r}=$ - 0.106, $p>0.05$ ) of potential entrepreneurs of university level students.

This study is found that $(\mathrm{r}=0.225, \mathrm{p}<0.01$ and $\mathrm{r}=0.390, \mathrm{p}<0.01)$ which implies there is a statistical significant positive correlation between locus of control and entrepreneurial affinity in the case of both small scale live 
entrepreneurs and potential entrepreneurs of university level students. Similarly, Neill (2006) found that an individual with internal locus of control tends to be entrepreneur and they are enthusiastic and willing to explore their talents as well as any opportunity. Gartner (1990) supported that an individual with internal locus of control will be more independent, self confident, realize an ideal, control events and good in decision making which support to be entrepreneur. There is a statistical significant positive correlation between entrepreneurial affinity and risk taking propensity $\left(r=0.272^{* *}, p<0.01\right.$ and $\left(r=0.272^{* *}, p<0.01\right)$ in the case of both small scale live entrepreneurs and potential entrepreneurs of university level students. Amit, Glosten and Muller (1993) strongly supported that entrepreneurs as a group have a above-average propensity to taking risks. There is a statistical significant positive correlation between entrepreneurial affinity and need for achievement $\left(\mathrm{r}=0.236^{* *}, \mathrm{p}<0.01\right.$ and $\left(\mathrm{r}=0.400^{* *}, \mathrm{p}<0.01\right)$ in the case of both small scale live entrepreneurs and potential entrepreneurs of university level students. The strongest association was found between entrepreneurial intentions and the proactive personality scale (Fama, 1980) which have been shown in this study $\left(r=0.368^{* *}, p<0.01\right.$ and $\left.r=0.368^{* *}, p<0.01\right)$ in the case of both small scale live entrepreneurs and potential entrepreneurs of university level students. Crant (1993) found that the proactive personality and vocational training have also influence of creating entrepreneurship. Participation in entrepreneurship education has been associated with the increasing interest towards choosing entrepreneurship as a viable career option. It is found that $(r=0.205, p<0.01$ and $\mathrm{r}=0.357, \mathrm{p}<0.01)$ which implies there is a statistical significant positive correlation between entrepreneurship education and entrepreneurial affinity in the case of both small scale live entrepreneurs and potential entrepreneurs of university level students. Peterman and Kennedy (2003) revealed that entrepreneurship courses to all students so as to improve their entrepreneurial intention. Souitaris, Zerbinati, and Al-Laham (2007) found that entrepreneurship education increases entrepreneurial intention.

Fleming (1996) supported that entrepreneurship education creates and increases awareness as well as promotes self employment as a career choice of entrepreneurship. Volery and Mueller (2006) emphasized that the entrepreneurship education influences an individual's decision to become an entrepreneur .Entrepreneurship education has been also recognized by Kolvereid and Moen (1997) as a vital influence of students' career decisions. The family business can influence entrepreneurial intent (Ajzen and Fishbein, 1980). The relationship between entrepreneurial affinity and family business background has been found in this study $(\mathrm{r}=0.410, \mathrm{p}<0.01)$ of small scale live entrepreneurs which implies there is a statistical significant positive correlation between entrepreneurship education and entrepreneurial affinity in the case of small scale 
live entrepreneurs. It is supported by Autio et al, (1997) and Kirkwood (2007) the family business background is acted as personal own experiences about entrepreneurship to advanced entrepreneurial preference. In this research, it is true for small scale live entrepreneurs But there is a negative correlation between a family business background and entrepreneurial affinity $(r=-0.106, p>0.05)$ in the case potential entrepreneurs of university level students.

\section{CONCLUSIONS AND RECOMMENDATIONS}

Entrepreneurs play a vital role for economic development of any country by their contributions. They introduce new ways of starting new business, can make change the market, bring new products for the society and create employment opportunity for the people of the country. The research findings suggest that there is statistical significant relationship between locus of control, risk taking propensity, need for achievement, proactive propensity, entrepreneurship education, family business background and entrepreneurial affinity of small scale live entrepreneurs and potential entrepreneurs of university level students . The study found that there are some characteristics which are positively correlated of entrepreneurship intention such as need for achievement, locus of control, risk-taking propensity, tolerance for uncertainty, and Type-A behavior (Furnham 1992). A study suggested that the influence of locus of control is the potential ability to perceive opportunities on entrepreneurs (Brockhans and Horwitz 1986). (Cromie, 1987) addressed several human attributes, such as desire for independence, internal locus of control are responsible of being entrepreneur.

Family business background was found to have a strong positive correlation to entrepreneurial affinity of small scale live entrepreneurs but negative relationship of potential entrepreneurs of university level students. Entrepreneurship education program was also found to be correlated with entrepreneurial affinity of small scale live entrepreneurs and potential entrepreneurs of university level students. Autio et al, (1997) investigated and found that the support from university environment affects the entrepreneurial confidence of university level students. Business education support necessary knowledge about entrepreneurship (Garavan \& O'Cinneide, 1994). A study pointed that entrepreneurship education, provides knowledge to enhance entrepreneurs (Galloway \& Brown, 2002). Therefore, it is recommended that government should more focus of entrepreneurship education for schools, college and university level students by expanding the practical aspects of the curricular relating to entrepreneurship education and they should be sponsored to attend workshops, seminars, conferences regarding entrepreneurship development. 
People who want to run businesses need know their own strengths and weaknesses because entrepreneurship involves the ability, skills and talents.

After analyzing the data the study reached to the conclusion that family business background is the most important factor to pick up decision of entrepreneurial affinity to the small scale live entrepreneurs. The need for achievement is the highly influential factor of picking-up decision of potential entrepreneurs of university level students.

\section{REFERENCES}

Ajzen I, Fishbein M. (1980). Understanding Attitudes and Predicting Social Behavior. Englewood Cliffs, N.J.: Prentice-Hall.

Amit, Glosten and Mueller (1993). Challenges to Theory Development in Entrepreneurship Research, The Journal of Management Studies, 30: 815.

Ancona, D. (1987). Groups in Organizations: Extending Laboratory Models, Beverly Hills, CA: Sage Publications.

Autio, E., Keeley, R.H., Klofsten, M. \& Ulfstedt, T. (1997). Entrepreneurial Intent Among Students: Testing an Intent Model in Asia, Scandinavia and USA, Frontiers of Entrepreneurship Research, Babson Conference Proceedings. Retrieved from http:// www.babson.edu/entrep/fer

Ayodele, K. O. (2013). Demographics, entrepreneurial self-efficacy and locus of control as determinants of adolescents' entrepreneurial intention in Ogun State, Nigeria, European Journal of Business and Social Sciences, 1(12): 59-67.

Basu, A, \& Virick M. (n.d.), Assessing Entrepreneurial Intentions Amongst Students: A Comparative Study, available online on http://nciia.org/conf08/assets/pub/basu2.pdf accessed on April 05, 2013.

Bechard, J.P. \& Toulouse, J.M. (1998). Validation of a didactic model for the analysis of training objectives in entrepreneurship, Journal of Business Venturing, 13(4): 317-332.

Brief, A. and Aldag, R. (1981). The "Self" In Work Organizations, Academy of Management Review, 6: 75-88.

Brockhaus, R.H. (1980). Risk-taking Propensity of Entrepreneurs, Academy of Management Journal. 23(3): 509-520.

Brockhaus, Robert H. (1982). "The Psychology of the Entrepreneur," Encyclopedia of Entrepreneurship, Ed. Calvin Kent, Donald L. Sexton, and Karl H. Vesper. Englewood Cliffs, N.J.: Prentice Hall: 39-56. 
Brockhaus, Robert H., and Pamela S. Horwitz (1986). The Psychology of the Entrepreneur, The Art and Science of Entrepreneurship. Ed. Donald L. Sexton and Raymond W. Smilor, Cambridge, Mass.: Ballinger: 25-48.

Carr, J.C. \& Sequeira, J.M. (2007), Prior family business exposure as intergenerational influence and entrepreneurial intent: A theory of Planned Behavior approach, Journal of Business Research, 60: 1090-1098.

Chang,E. Memili, E. Chrisman, J. Kellermans, F. and Chua, J. (2009). Family social capital, venture preparedness, and start-up decisions - A study of Hispanic entrepreneurs in New England, Family Business Review, 22 (3): 279-292.

Clayton, G. (1989). Entrepreneurship education at the postsecondary level. Retrieved December 3, 2013, from www.celcee.edu/abstracts/c19981683.html.

Crant, J. Michael (1995). The Proactive Personality Scale and Objective Job Performance Among Real Estate Agents, Journal of Applied Psychology 80 (4): 532-537.

Crant, J. Michael(1996), The proactive personality scale as a predictor of entrepreneurial intentions, Journal of Small Business Management, 34 (3):42

Cromie, S. (1987). Motivations of Aspiring Male and Female Entrepreneurs, Journal of Organizational Behaviour, 8: 251-261.

Davidsson, P.( 2006). Nascent entrepreneurship: Empirical studies and developments, Foundations and Trends in Entrepreneurship Theory and Practice 2(1): 1-76.

Duygulu, E. (2008). Institutional Profiles and Entrepreneurship Orientation: A Case of Turkish Graduate Student, MPRA 16(11): 7247

Fama, E. F. (1980). Agency problems and the theory of the firm, Journal of Political Economy, 88: 288-307.

Fleming, P. (1996). Entrepreneurship education in Ireland: A longitudinal study. Academy of Entrepreneurship Journal 2(1): 95-119.

Furnham, Adrian (1992). Personality at Work: The Role of Individual Differences in the Workplace, London, England: Routledge.

Galloway, L. and Brown, W. (2002). Entrepreneurship Education at University: A Driver in the Creation of High Growth Firms? Education Training ,44(8/9): 398-405

Garavan, T.N. and O'Cinneide, B. (1994). Entrepreneurship Education and Training Programmes: A Review and Evaluation, Journal of European Industrial Training, 18(8): 3-12.

Gartner, W.B (1990). A conceptual framework for describing the phenomenon of new venture creation, Academy of management review 10: 696-706 
Gorman, G., Hanlon, D., \& King, W. (1997). Some research perspectives on entrepreneurship education, enterprise education and education for small business management: a ten-year literature review, International Small Business Journal. 15(3): 56-79.

Hansemark, O. (1998). The effects of an entrepreneurship programme on need for achievement and locus of control of reinforcement, International Journal of Entrepreneurship Behaviour and Research,4(1): 28-50.

Kaufmann, P. \& Welsh, D. (1995). Locus of control and entrepreneurship in the Russian Republic, Entrepreneurship: Theory and Practice, 20(1): 43-56.

Kirkwood, J. (2007). Igniting the entrepreneurial spirit: Is the role parents play gendered? International Journal of Entrepreneurial Behaviour and Research 13(1): 39-59.

Kolvereid, L. and O. Moen (1997). Entrepreneurship among business graduates: does a major in entrepreneurship make a different? Journal of European Industrial Training 21(4): 154-160.

Krueger, N. (1993). The impact of prior entrepreneurial exposure on perceptions of new venture feasibility and desirability. Entrepreneurship: Theory and Practice, 18(1): 5-21.

Liñán, F. (2004). Intention-Based Models of Entrepreneurship Education, Piccolla Impresa/Small Business, 3 :11-35.

M. Z. Zahariah, M. A. Amalina, K. G. Erlane, Z. M. Zain, A. M. Akram, and E. K. Ghani, (2010) Entrepreneurship Intention Among Malaysian Business Students, L'esprit D'entreprise Chez Les Etudiants En Commerce Malaisiens., 6( 3): 3444.

Miles, R. and Snow, C. (1978). Organizational Strategy, Structure, and Process, New York: McGraw-Hill.

Neill, J. (2006). What is locus of control, http://widerdom.com/psychology/ loc/locusofcontrol/whatis, html

Nicholson, L., Anderson, A. R.(2005). News and Nuances of the Entrepreneurial Myth and Metaphor: Linguistic Games in Entrepreneurial Sense-Making and SenseGiving, Entrepreneurship Theory and Practice :153-172.

O. Y. Keat, C. Selvarajah, and D. Meyer(2006). Inclination towards entrepreneurship among university students : An empirical study of Malaysian university students, Journal of Business, 2(4): 206-220. 
Peterman, N. \& Kennedy, J. (2003). Enterprise Education: Influencing Students' Perceptions of Enterprise Education, Entrepreneurship Theory and Practice, 28(2): 129-144.

Perry, C. (1990). After Further Sightings of the Heffalump. Journal of Managerial Psychology 5 (2): 22-31.

Robbins, S.P. (2003). Organizational Behavior. (International edition), New Jersey: Prentice Hall.

Rotter, J. (1966). Generalized expectancies for internal versus external control of reinforcements, Psychological Mono-graphs.

Rotter, J.B. (1990). Internal Versus External Locus of Control: A Case Story of a Variable, American Psychologist : 489-493.

Souitaris, V., Zerbinati, S., \& Al-Laham, A. (2007). Do Entrepreneurship Programmes Raise Entrepreneurial Intention of Science and Engineering Students? The Effect of Learning, Inspiration and Resources, Journal of Business venturing, 22: 566-591

Vesper, K.H. (1990). New Venture Strategies, Prentice-Hall, Englewood Cliffs, N.J.

Volery, T. and S. Mueller (2006). A conceptual framework for testing the effectiveness of entrepreneurshipeducation programmes towards entrepreneurial intention, 51st ICSB World Conference Melbourne, Australia.

Wilson, F., J. Kickul, and D. Marlino (2007). Gender, entrepreneurial self-efficacy, and entrepreneurial career intentions: Implications of entrepreneurship education, Entrepreneurship: Theory and Practice 31 (3): 387- 406.

Yeboah, A. S., Kumi, E., \& Awuah, J. B. (2013). An Assessment of Entrepreneurship intention Among Sunyani Polytechnic Marketing Student, International Review of Management and Marketing, 3(1): 37- 49.

Zeithaml, V. and Zeithaml, C. (1984). Environmental Management: Revising the Marketing Perspective, Journal of Marketing 48: 46-53.

Zeithaml, Carl P., Rice, Jr., George H.(1987). Entrepreneurship/Small Business Education in American Universities, Journal of Small Business Management: 44-50 